\title{
Identifikasi Jalur Sesar Opak Berdasarkan Analisis Data Anomali Medan Magnet dan Geologi Regional Yogyakarta
}

\author{
Ira Maya Fathonah ${ }^{1}$, Nugroho Budi Wibowo ${ }^{2}$, dan Yosaphat Sumardi ${ }^{1}$ \\ ${ }^{1}$ Fakultas Matematika dan Ilmu Pengetahuan Alam, Universitas Negeri Yogyakarta \\ ${ }^{2}$ Badan Meteorologi Klimatologi dan Geofisika, Yogyakarta \\ Email: ira.maya.fathonah@gmail.com
}

Received 21-08-2014, Revised 22-09-2014, Accepted 20-10-2014, Published 31-10-2014

\begin{abstract}
This research was aimed to know the magnetic field anomaly pattern upon Opak's fault, to identify the direction of Opak's fault and the structure of Opak's fault based on Geomagnetic data. It was conducted in the vicinity of Opak's fault in Pundong sub-district, Yogyakarta. It used magnetic method which is based on rocks magnetic susceptibility. The data were taken by G-856AX Proton Precision Magnetometer (PPM) using looping method. Data analysis was done using diurnal variation and IGRF correction, reduction to pole, upward continuation and under surface structure modelling. From magnetic field anomaly analysis, it was discovered that magnetic field anomaly on Opak's fault has $-50 \mathrm{nT}$ negative closure in the East, and 100 nT positive closure in the West. According to the result interpretation of $2.5 \mathrm{D}$ model on two slices using Mag2DC software, it can be obtained that the under surface structure of Opak's fault consist of Young Alluvial formation, Nglanggran formation, Semilir formation, Kebo Butak formation, and Wungkal Gamping with various thickness. The location of this Opak's fault is almost the same with the location of Opak's fault in Yogyakarta geology map. Opak's fault around Pundong sub-district is a normal fault directed to $\mathrm{N} 35^{\circ}$ E. The eastern part of the fault has a relatively constant movement, while the western part is relatively moving down.
\end{abstract}

Keywords: magnetic field anomaly, magnetic method, Opak's fault, under surface structure, Yogyakarta

\section{ABSTRAK}

Penelitian ini bertujuan untuk mengetahui pola anomali medan magnet jalur Sesar Opak, mengidentifikasi arah jalur sesar Opak dan struktur bawah permukaan jalur Sesar Opak berdasarkan data Geomagnetik. Lokasi Penelitian berada pada jalur sesar Opak di sekitar Kecamatan Pundong, Yogyakarta. Metode yang digunakan adalah metode magnetik yang didasarkan pada sifat suseptibilitas (kerentanan) magnetik batuan. Pengambilan data menggunakan alat Proton Precision Magnetometer (PPM) tipe G-856AX dengan metode looping. Analisis metode magnetik dilakukan dengan koreksi variasi harian dan koreksi IGRF, reduksi anomali ke kutub, anomali kontinuasi ke atas dan pemodelan struktur bawah permukaan. Setelah dilakukan analisis anomali medan magnet diketahui bahwa anomali medan magnet pada jalur sesar Opak mempunyai sepasang klosur, yaitu klosur negatif dengan nilai 50nT pada bagian timur, dan klosur positif dengan nilai $1100 \mathrm{nT}$ di bagian barat. Berdasarkan hasil interpretasi dari pemodelan 2,5D pada dua sayatan menggunakan software Mag2DC for windows didapatkan bahwa struktur bawah permukaan jalur sesar Opak hasil penelitian terdiri dari formasi Alluvial Muda, Formasi Nglanggran, Formasi Semilir, Formasi Kebo Butak, dan formasi Wungkal Gamping dengan ketebalan bervariasi. Letak jalur Sesar Opak pada daerah penelitian hampir sama dengan letak Sesar Opak pada peta geologi Yogyakarta. Sesar Opak di sekitar Kecamatan Pundong merupakan sesar normal berarah N 35 $5^{\circ}$ e dengan bagian barat relatif bergerak turun sedangkan bagian timur relatif tetap.

Kata kunci : anomali medan magnet, metode magnetik, sesar Opak, struktur bawah permukaan, Yogyakarta 


\section{PENDAHULUAN}

Pada tanggal 27 Mei 2006 daerah Yogyakarta dan sekitarnya diguncang gempa sebesar 5,9 skala Richter yang menelan banyak korban jiwa. Berdasarkan hasil kajian deformasi koseismik yang dilakukan oleh tim peneliti dari Teknik Geodesi ITB dari hasil survei GPS menyimpulkan bahwa sesar penyebab gempa bumi 27 Mei 2006 adalah sesar jenis sinistral dengan panjang $18 \mathrm{~km}$ lebar $10 \mathrm{~km}$ strike $48^{\circ}$ dan dip $89^{\circ}$ dan berada di sebelah timur 3-4 km dari lokasi Sesar Opak di kawasan Gunung Kidul yang biasa digambarkan sepanjang Sungai Opak ${ }^{[1]}$. Hasil survei GPS juga memperlihatkan bahwa komponen horizontal deformasi pascaseismik gempa Yogyakarta berkisar antara $0,3 \mathrm{~cm}$ dan $9,1 \mathrm{~cm}$ dalam periode Juni 2006 sampai Juni 2008.

Apabila pada deformasi koseismik mempunyai pergerakan sinistral, maka deformasi pascaseismik menunjukkan pergerakan dekstral dari daerah sebelah timur Sesar Opak (kawasan Gunung Kidul) terhadap kawasan sebelah baratnya yang relatif lebih stabil ${ }^{[2]}$. Sedangkan dari pemetaan Sesar Opak dengan metode gravitasi yang dilakukan oleh tim peneliti UNDIP menyimpulkan bahwa di daerah Parangtritis dan sekitarnya terdapat dua buah sesar, salah satunya adalah Sesar Opak dengan arah $\mathrm{N} 30^{\circ} \mathrm{E} / 60^{\circ}$ dan merupakan jenis sesar normal atau sesar turun di mana blok barat relatif bergerak turun sedangkan blok timur relatif tetap ${ }^{[3]}$.

Hasil interpretasi kualitatif dan kuantitatif dari pemodelan zona Sesar Opak di daerah Pleret, Bantul, Yogyakarta dengan metode gravitasi didapatkan adanya dugaan sesar normal dengan struktur lapisan terdiri dari tiga lapisan yaitu batuan gamping, batuan breksi dan batuan penutup permukaan yang meliputi endapan alluvial dan endapan sungai Opak ${ }^{[4]}$ dan berdasarkan hasil interpretasi kualititatif pada peta kontur anomali Bouguer menunjukkan adanya kelurusan yang berarah timur laut-barat daya. Indikasi Sesar Opak adalah sesar turun, dengan blok timur tetap dan blok barat relatif turun. Interpretasi kuantitatif struktur bawah permukaan diperoleh densitas batuan formasi Sesar Opak sebesar $2,6 \mathrm{~g} / \mathrm{cm}^{3}$ hingga $2,7 \mathrm{~g} / \mathrm{cm}^{3}$ yang merupakan batuan breksi lapili dan batuan breksi andesit tua. Alluvium sebagai formasi penutup dengan densitas $1,85 \mathrm{~g} / \mathrm{cm}^{3}$. Kedalaman rata-rata Sesar Opak berkisar antara 55 hingga $82 \mathrm{~m}$, sedangkan pergeserannya berkisar antara 5 hingga $10 \mathrm{~m}^{[5]}$. Karena akibat dari kegempaan di daerah Sesar Opak tergolong cukup besar, makaperludiketahui jalur dan karakteristik Sesar Opak untuk meminimalisir dampak dari sesar tersebut.

Dalam penelitian ini, penulis menggunakan metode magnetik, yaitu metode yang digunakan untuk mengetahui kondisi bawah permukaan bumi berdasarkan sifat suseptibilitas (kerentanan) magnetik batuan. Metode ini dipilih karena masih sedikit penelitian tentang Sesar Opak yang menggunakan metode magnetik, sehingga diharapkan dapat memperjelas karakteristik dan jalur Sesar Opak.

\section{METODE}

Pengambilan data dilaksanakan selama 3 hari yaitu Rabu, 27 November 2013, Kamis, 28 November 2013, dan Selasa, 3 Desember 2013. Penelitian ini dilakukan di Kecamatan Pundong, Kabupaten Bantul, Yogyakarta pada koordinat 757'24.8" LS sampai 759'36,5" LS dan $110^{\circ} 19^{\prime} 01,3^{\prime \prime}$ BT sampai $110^{\circ} 21^{\prime} 03,0^{\prime \prime}$ BT. Penelitian dilakukan di daerah ini karena diduga merupakan daerah yang menjadi jalur Sesar Opak sesuai dengan peta geologi Yogyakarta (Gambar 1). 


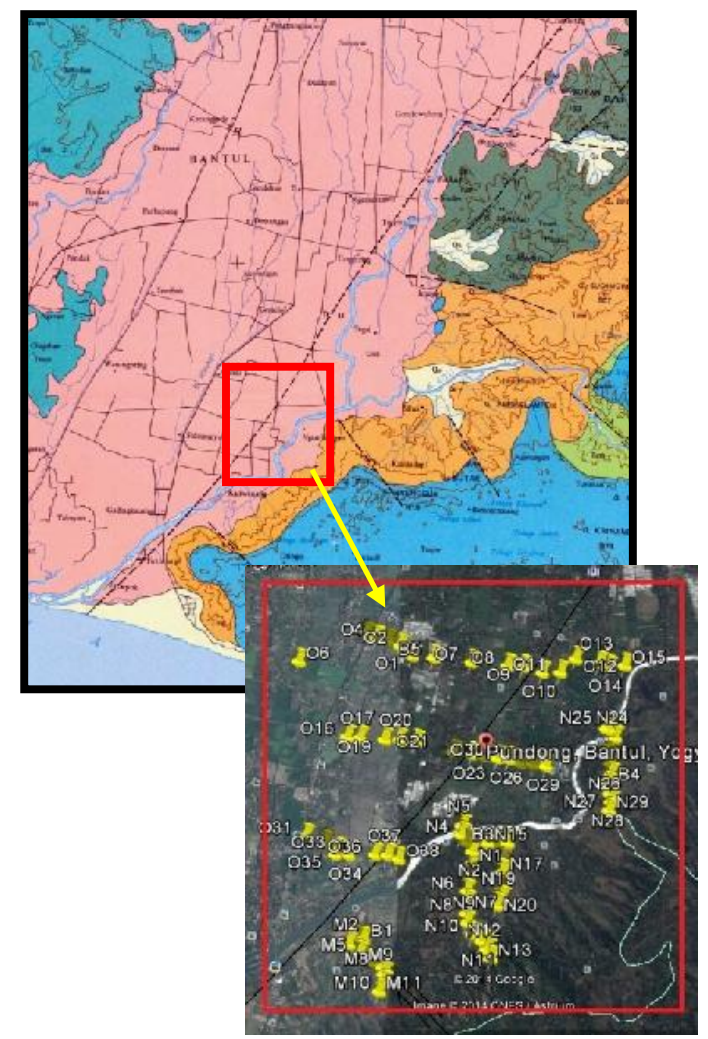

Gambar 1. (color online) Letak Daerah Penelitian dalam Peta Geologi Yogyakarta ${ }^{[6]}$

Pada penelitian ini, pengukuran titik data berjarak 100-200m sehingga diperoleh 91 titik data. Alatyang dipergunakan meliputi: satu buah Proton Precession magnetometer (PPM)model G-856 Geometrics untuk merekamwaktu dan medan magnet total (dalam satuan nT), satu buah Global Positioning System(GPS) untuk menentukan posisi penelitian dan sebuah kompas geologi untuk menentukan arah geografi lokasi pengukuran.Proton Precession magnetometer (PPM) yang digunakan hanya satu maka pengambilan data dilakukan dengan cara Looping, artinya pengukuran dimulai dari base dan diakhiri di base lagi, di mana satu alat PPM menjadi base sekaligus rover.

Data hasil pengukuran di lapangan yang berupa data mentah merupakan data medan magnet total yang masih dipengaruhi oleh medan utama magnet bumi (IGRF) dan medan magnet luar. Anomali medan magnet didapatkan dengan menghilangkan pengaruhpengaruh tersebut terlebih dahulu, yaitu dengan melakukan koreksi harian dan koreksi nilai intensitas medan magnet utama bumi atau International Geomagnetic Reference Field (IGRF). Medan anomali magnet total dihitung dengan persamaan:

$$
\Delta T=H t-H l-H o
$$

Dengan $H t$ adalah nilai medan magnet terukur, $H l$ adalah variasi harian medan magnet terukur, dan $\mathrm{Ho}$ adalah medan magnet utama bumi (IGRF) yang dihitung menggunakan software Geomag.70. Setelah melakukan perhitungan selanjutnya dibuat kontur medan magnet total menggunakan software Surfer 11. 


\section{Reduksi ke Kutub}

Reduksi ke kutub dilakukan dengan mengubah arah medan magnet yang awalnya dipole menjadi monopole, untuk memperjelas anomali medan magnet. Hal tersebut dilakukan dengan cara membuat sudut inklinasi benda menjadi $90^{\circ}$ dan deklinasinya $0^{\circ}$. Dengan demikian anomali monopol yang dihasilkan berasal dari sumber yang sama. Reduksi ke kutub ini dilakukan dengan menggunakan software Magpick.

\section{Kontinuasi ke Atas}

Kontinuasi ke atas dilakukan dengan mengolah data medan magnet total menggunakan software Magpick. Hal ini bertujuan untuk menghilangkan pengaruh lokal yang berasal dari sumber-sumber di permukaan, dan memperjelas pengaruh anomali regional. Semakin tinggi kontinuasi data, informasi lokal semakin hilang, dan informasi regional semakin jelas. Kontinuasi ke atas dilakukan setelah data anomali medan magnetik total diketahui dan telah dikontur menggunakan software Surfer.

\section{Interpretasi}

Interpretasi digunakan untuk menentukan posisi struktur geologi bawah permukaan yang ada pada daerah penelitian. Interpretasi dilakukan setelah data medan magnetik total dikoreksi dengan efek regional dan kontur medan magnetik total telah direduksi ke kutub. Interpretasi kualitatif bertujuan untuk mengetahui posisi benda penyebab anomali berdasarkan hasil analisis pada anomali magnetik yang terdapat pada peta anomali regional dan peta anomali lokal. Interpretasi kuantitatif dilakukan dengan pembuatan model dari peta anomali regional yang telah dibuat menggunakan software Surfer.

Peta anomali tersebut dibuat sayatan yang melewati anomali yang diduga sebagai lokasi jalur sesar Opak. Pemilihan posisi sayatan berdasarkan hasil interpretasi kualitatif. Sayatan kemudian dimodelkan dengan menggunakan softwareMag2DC for windows. Pemodelan dilakukan dengan mempertimbangkan faktor geologi sebagai indikator kecocokan antara hasil observasi lapangan dengan data.

\section{HASIL DAN PEMBAHASAN}

Gambar 2 menunjukkan adanya klosur positif dan klosur negatif terlihat cukup banyak. Pasangan klosur positif dan klosur negatif ini menunjukkan bahwa anomali magnetik berupa dipole (dwi kutub).

Nilai klosur positif dan klosur negatif di daerah penelitian adalah $1100 \mathrm{nT}$ dan $-50 \mathrm{nT}$. Sudut inklinasi medan magnetik pada daerah penelitian adalah $-33,567^{\circ}$ dan sudut deklinasi sebesar $1,117^{\circ}$. Sumber anomali yang dalam akan menghasilkan kontur dengan frekuensi lebih rendah yang akan terlihat sebagai klosur besar, sedangkan sumber anomali yang terletak lebih dangkal akan menghasilkan klosur yang relatif kecil. Dari peta anomali medan magnet tersebut telah terlihat anomali-anomali yang menunjukkan perbedaan dengan lingkungan sekitarnya. Skala warna yang berada di sebelah kanan peta anomali medan magnet menunjukkan tingkat besarnya anomali medan magnet, warna semakin merah pada peta anomali medan magnet menunjukkan nilai intensitas magnetik yang semakin tinggi dan warna yang semakin biru menunjukkan nilai intensitas magnetik yang semakin rendah. 


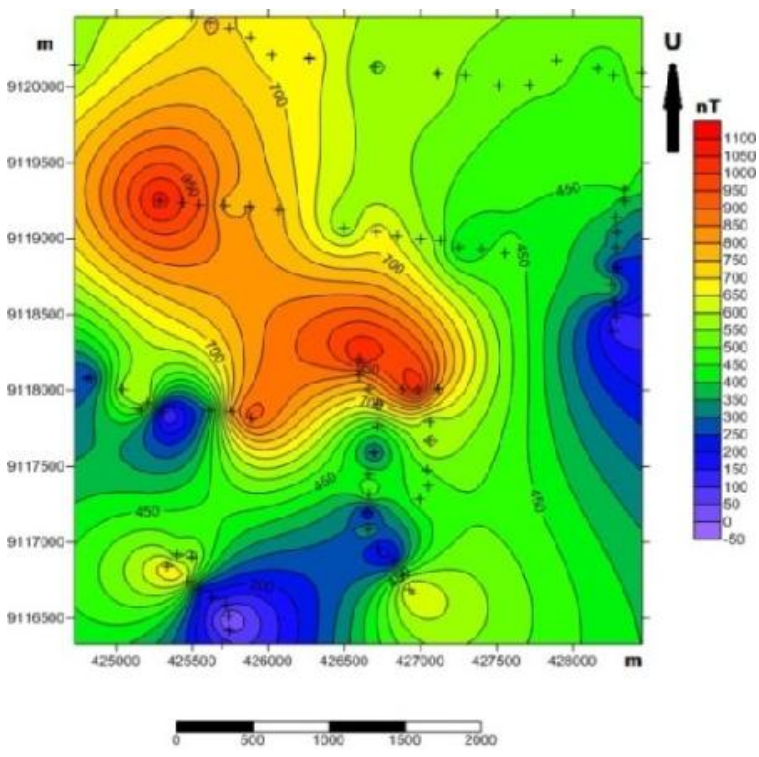

Gambar 2. (color online) Kontur Medan Magnet Total

\section{Hasil Reduksi ke Kutub}

Data anomali medan magnetik hasil koreksi variasi harian dan IGRF kemudian direduksi ke kutub dengan tujuan agar dapat melokalisasi daerah-daerah dengan anomali maksimal yang tepat berada di atas tubuh benda penyebab anomali. Reduksi ke kutub dilakukan dengan cara membuat sudut inklinasi benda menjadi $90^{\circ}$ dan deklinasinya $0^{\circ}$.

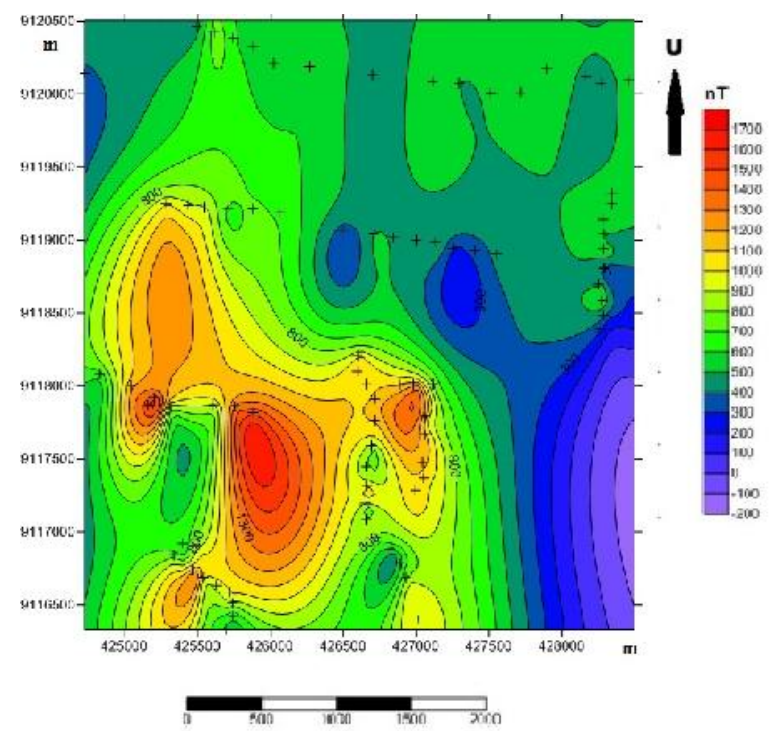

Gambar 3. (color online) Kontur Anomali Medan Magnet Total Hasil Reduksi Ke Kutub 
Hal tersebut dilakukan untuk membuat anomali medan magnet total yang sebelumnya dipole menjadi monopole. Interpretasi kualitatif dapat langsung dilakukan pada kontur anomali medan magnetik hasil reduksi ke kutub ini.Kontur anomali medan magnetik yang telah direduksi ke kutub dapat dilihat dalam Gambar 3.

\section{Hasil Kontinuasi ke Atas}

Kontinuasi ke atas bertujuan untuk proses low pass filtering, yaitu untuk memperoleh peta anomali regional. Proses kontinuasi ke atas adalah proses transformasi anomali dari suatu level ke level yang lebih tinggi. Pada penelitian ini dilakukan kontinuasi ke atas secara sistematis dari ketinggian $100 \mathrm{~m}, 500 \mathrm{~m}, 1000 \mathrm{~m}, 1500 \mathrm{~m}, 2000 \mathrm{~m}$, dan $2500 \mathrm{~m}$, tujuannya adalah untuk mendefinisikan anomali regional daerah penelitian yang dapat dilihat dari pola anomali pada ketinggian tertentu yang tidak mengalami perubahan lagi ketika dinaikkan ke level yang lebih atas lagi. Pengangkatan ke atas pada ketinggian $2500 \mathrm{~m}$ ditunjukkan pada Gambar 4.

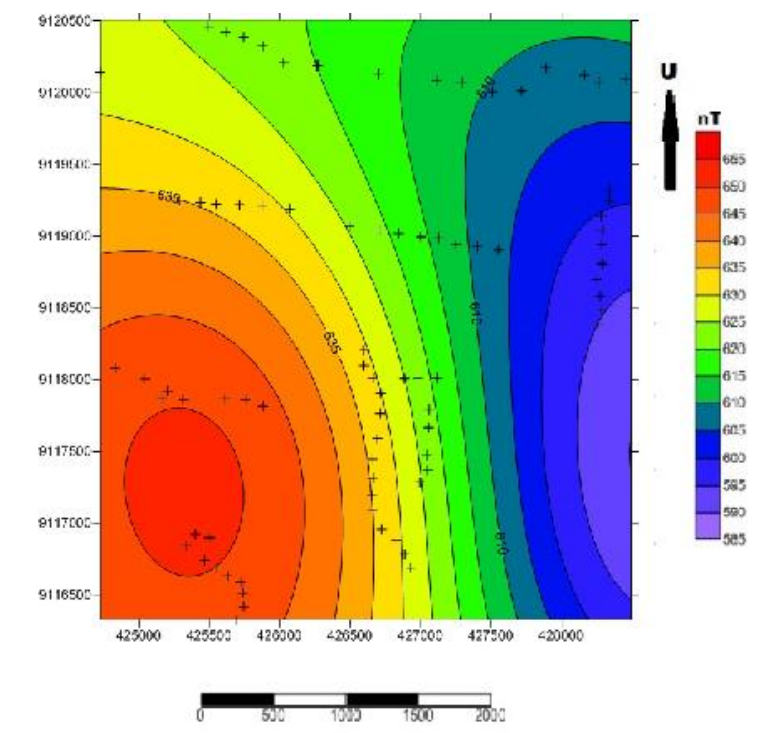

Gambar 4. (color online) Kontur Anomali Kontinuasi Ke Atas 2500 m

\section{Interpretasi}

Dalam penelitian ini diambil dua sayatan yaitu sayatan A-A' dan sayatan B-B' yang ditunjukkan pada Gambar 5. Dari hasil sayatan A-A' dan sayatan B-B' dibuat pemodelan struktur bawah permukaan dengan kedalaman 2500m yang di harapkan dapat memperoleh kenampakan sesar Opak. 


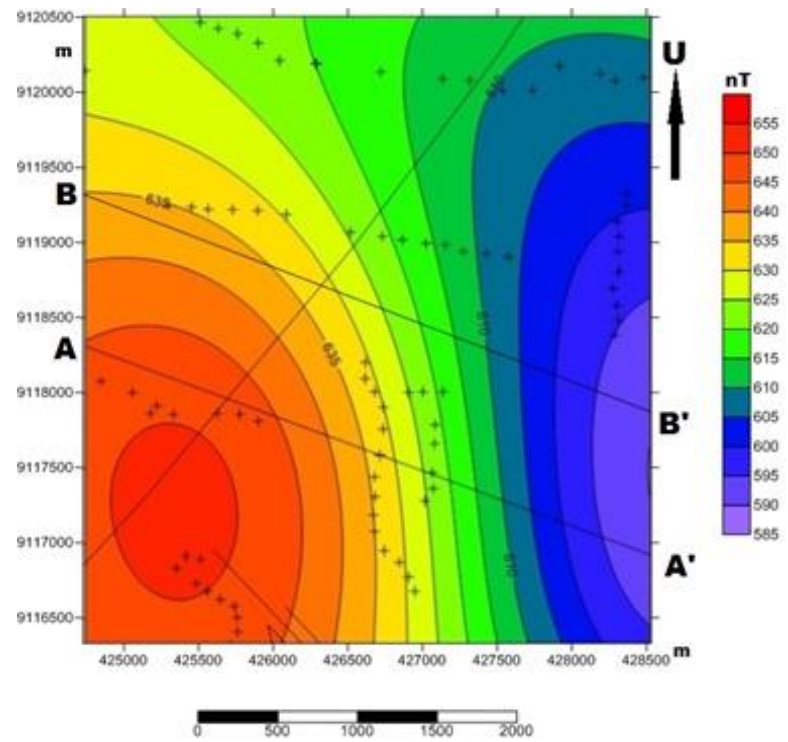

Gambar 5. (color online) Letak sayatan pada kontur anomali medan magnet ketinggian $2500 \mathrm{~m}$

Dari hasil pemodelan menggunakan software Mag2DC yang ditunjukkan pada Gambar 67terlihat adanya patahan struktur lapisan batuan, sehingga ketika dibuat model sayatan struktur bawah permukaan seperti pada Gambar 8 dapat disimpulkan bahwa terdapat sebuah sesar yang terletak dibagian barat sungai Opak. Hal tersebut sesuai dengan peta jalur sesar Opak yang terdapat dalam peta geologi Yogyakarta.

Berdasarkan Gambar 8, struktur bawah permukaan pada sayatan A-A' dan sayatan B-B' menunjukkan formasi batuan penyusun yang didominasi oleh batuan sedimen, yaitu batuan serpih dengan nilai suseptibilitas sekitar 0,6 (dalam SI), batupasir dengan nilai suseptibilitas sekitar 0,4 (dalam SI), batu kapur dengan nilai suseptibilitas sekitar 0.3 (dalam SI), dan dolomit dengan nilai suseptibilitas sekitar 0,1 (dalam SI).

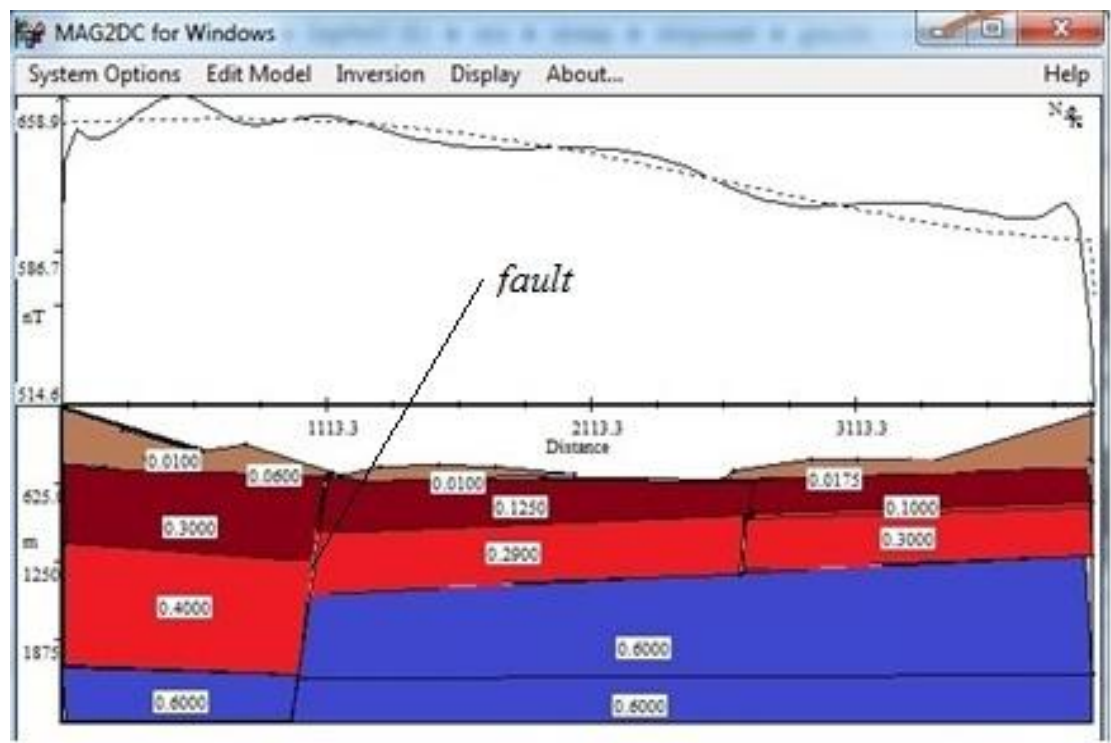

Gambar 6. (color online) Pemodelan struktur bawah permukaan pada sayatan A-A'dengan Mag2DC for windows 


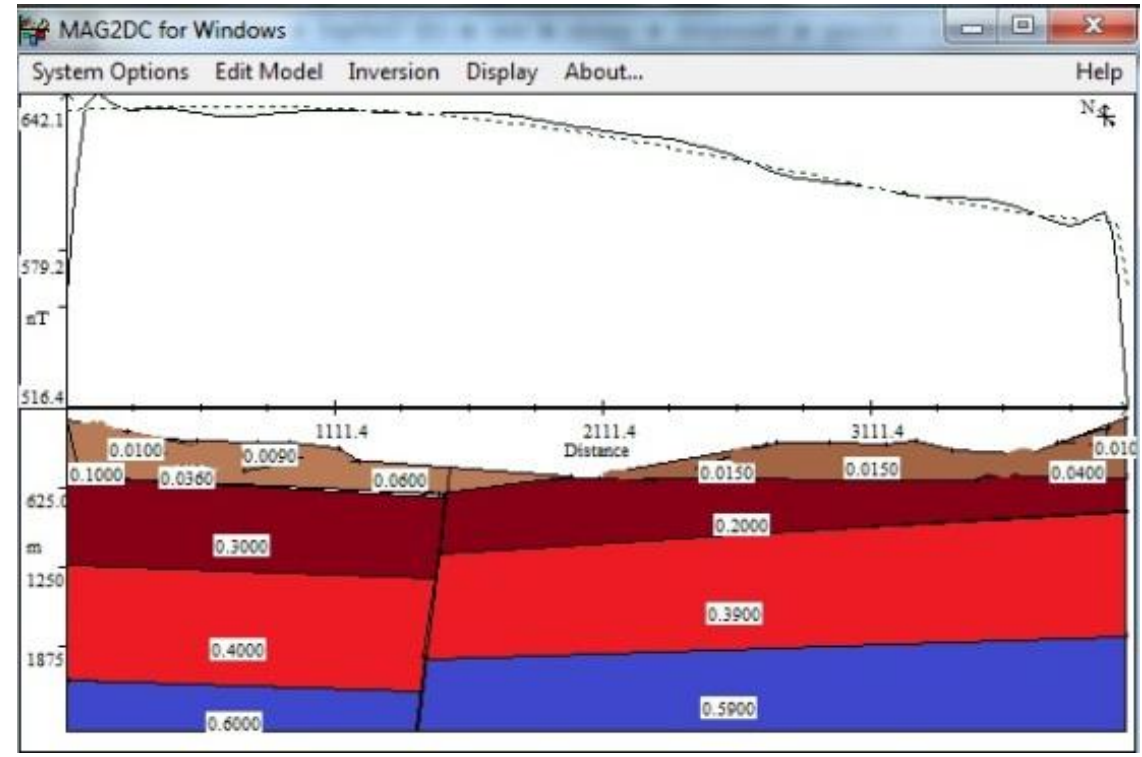

Gambar 7. (color online) Pemodelan struktur bawah permukaan pada sayatan B-B'dengan Mag2DC for windows

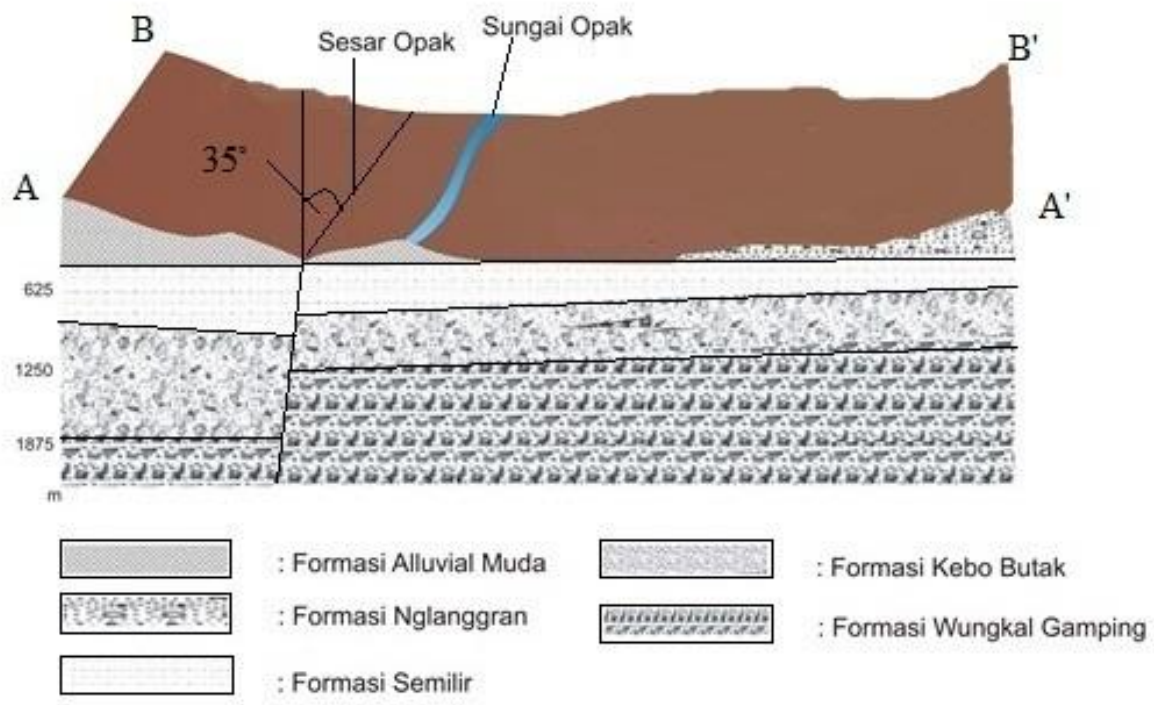

Gambar 8. (color online) Gambar Interpretasi Bawah Permukaan Daerah Penelitian pada sayatan A-A' dan B-B'

Formasi dan ketebalan struktur bawah permukaan hasil interpretasi pada sayatan A-A' dan B-B' dapat dilihat pada Tabel 1. 
Tabel 1. Formasi dan ketebalan struktur bawah permukaan hasil interpretasi pada sayatan A-A' dan B-B'

\begin{tabular}{|c|c|c|c|}
\hline \multirow[t]{2}{*}{ Formasi } & \multicolumn{2}{|c|}{ Ketebalan } & \multirow[t]{2}{*}{ Batuan Penyusun } \\
\hline & Sayatan A-A' & Sayatan B-B' & \\
\hline Alluvial Muda & $20 m-500 m$ & $20 m-625 m$ & batupasir dan dolomit \\
\hline Nglanggran & $50 m-480 m$ & $20 m-550 m$ & andesit dan breksi \\
\hline Semilir & $250 m-625 m$ & $250 m-625 m$ & serpih, tuf dan batupasir \\
\hline Kebo Butak & $500 m-1200 m$ & $625 m-1250 m$ & $\begin{array}{l}\text { batu pasir, batu lempung, dan } \\
\text { andesit }\end{array}$ \\
\hline Wungkal Gamping & $580 m-1225 m$ & $400 m-1000 m$ & batugamping dan batupasir \\
\hline
\end{tabular}

Dari hasil interpretasi bawah permukaan juga dapat disimpulkan bahwa sesar Opak merupakan jenis sesar normal atau sesar turun di mana bagian barat mengalami penurunan sedangkan bagian timur cenderung tetap. Hasil tersebut sesuai dengan hasil penelitian dari Irham,dkk (2010). Dari pergeseran letak sesar Opak antara pemodelan A-A' dengan pemodelan B-B' menunjukkan bahwa sesar berarah $\mathrm{N} 35^{\circ} \mathrm{E}$.

\section{KESIMPULAN}

1. Pola anomali medan magnet jalur sesar Opak di sekitar Kecamatan Pundong memiliki pasangan klosur negatif dengan nilai -50nT di bagian timur dan klosur positif dengan nilai $1100 \mathrm{nT}$ di bagian barat, berbedaan nilai anomali ini menunjukan bahwa daerah tersebut terdapat sesar.

2. Penyusun batuan struktur bawah permukaan di sekitar Kecamatan Pundong terdiri dari formasi Alluvial Muda, formasi Nglanggran, formasi Semilir, formasi Kebo Butak, dan formasi Wungkal Gamping. Sesar Opak merupakan sesar normal atau sesar turun dengan bagian barat mengalami penurunan sedangkan bagian timur cenderung tetap dengan arah $\mathrm{N} 35^{\circ}$ E dan berada di sebelah barat sungai Opak.

\section{DAFTAR PUSTAKA}

1 Abidin Z.H, Andreas H, Meliano, I, Gamal M, Usuma MA, Imata F, dan Ando, M. 2007. Deformasi Seismik Gempa Yogyakarta dari Survei GPS. Jurnal Geofisika Indonesia. Edisi 2007,No 1.

2 Abidin Z.H, Andreas .H, Meliano I, Gamal I, Gumelar I, dan Abdullah. 2009. Deformasi Koseismik dan Pascaseismik Gempa Yogyakarta 2006 dari Hasil Survei GPS.urnal Geologi Indonesia, Vol.4 No 4.

3 Nurwidyanto, M. Irham., Brotopuspito,.S., Waluyo., dan Sismanto. 2011. Study Pendahuluan Sesar Opak dengan Metode Gravitasi (Study Kasus Daerah Sekitar Kecamatan Pleret Bantul).Berkala Fisika Vol 14, No 1.

4 Nurwidyanto, M. Irham., Indriana, R.D., dan Darwis, Z.T,. 2007. Pemodelan Zona Sesar Opak di Daerah Pleret Bantul Yogyakarta dengan Metode Gravitasi. Berkala Fisika Vol 10. No.1.

5 Egie Wijaksono. 2008. Pemodelan Tiga Dimensi (3D) Zona Sesar Opak Bantul Yogyakarta Berdasarkan Data Anomali Bouguer Lengkap. Skripsi. Yogyakarta:UGM

6 Wartono Rahardjo, Sukandarrumidi, dan H.M.D. Rosidi. 1977. Peta Geologi Lembar Yogyakarta. Bandung: Direktorat Geologi. 